countries such as Great Britain, Germany and France. Probably this is due to the greater facilities of communication by other methods in the latter countries. Russia has come to the front as an electrical manufacturing country. This is shown by the fact that the value of its imports, which rose gradually from 3.62 million pounds in 1929 to $9 \cdot 15$ million pounds in 1932, has fallen rapidly to only $£ 789,000$ in 1935 . The outstanding example of self-sufficiency is the United States, the imports of which in 1935 were valued at only $£ 427,000$.

\section{Present State of British Bird Ringing}

The 1936 report on bird ringing in the British Isles (British Birds, April 1937) supports what the 1935 report indicated, namely, that future progress lies not in increasing the sum total, but rather in increasing the proportion of adult birds over nestlings, and scarcer species, marked. Although the total of 48,663 birds ringed is below the number for previous years, the total of trapped adult birds, 19,235, is a record, while that for nestlings (where mortality is naturally high) of 29,428 is a decline on the previous years. Dr. H. J. Moon again heads the list of ringers with 5,280 birds ringed, including 1,332 lapwings, 975 song thrushes, 849 blackbirds and 587 starlings; Mr. G. Charteris marked 3,524 birds, 1,166 of which were chaffinches, and Mr. E. Cohen marked 3,024 birds, including 865 shearwaters. There is an increasing number of birds ringed by schools and societies, and the two bird observatories. The Oxford Ornithological Society marked 2,639 birds, Bootham School 1,656, Rugby School 1,050, the Midlothian Ornithological Club 813, the British Empire Naturalists' Association 158, the Zoological Society 511 and Leighton Park School 403. Totals of ringed birds are not quite so significant as the numbers of birds of rarer species marked. Among the ringings of the Oxford Ornithological Society, for example, were 67 kingfishers, Skokholm Bird Observatory marked 27 white wagtails and 20 Greenland wheatears, Mr. A. Maynall marked 409 nightingales, Mr. C. Wontner Smith marked 201 rooks, Rugby School marked 169 rooks and 62 carrion-crows, Leighton Park School marked 21 fork-tailed petrels, Dartington Hall School 12 cirl buntings, the Isle of May Bird Observatory a barred warbler, two bluethroats and a Continental coal tit. Of the national total, the most numerous species ringed were : 3,191 lapwings, 2,155 Manx shearwaters, 1,530 Sandwich terns, 1,271 common terns and 1,131 herring-gulls.

\section{The National Institute of Agricultural Botany}

THE seventeenth report of the National Institute of Agricultural Botany, Cambridge, is now available, and copies may be obtained on application to the Institute (Huntingdon Road, Cambridge). The work of the Institute is directed to supplying the farmer with unbiased information as to the seeds he sows, and the report deals with methods by which this information was obtained in 1936. New varieties of all farm crops are tested by the Institute as soon as they appear, the trials being conducted on a field- scale at six permanent stations in England, and in some cases at additional centres on a farmer's own land. In all cases, the varieties are grown just as they would be by the farmer himself. Every feature of the varieties is noted and the results are often extremely enlightening. For example, of all the new varieties of winter wheat that have been tested in the last ten years, only one has proved to be worthy of general recommendation by the Institute. This is the Dutch variety 'Juliana', which has in the past two years' trials given slightly better results than 'Wilhelmina'. The position with other crops is very similar, and it is clear that farmers will be well advised, before deciding to grow a new variety, to apply to the agricultural organizer for their county, or direct to the Institute, for information as to the merits of the variety in question.

\section{"The Hero"}

LORD RAGLAN writes in reference to the review of his book "The Hero" appearing in NATURE (March 27, p. 532) : "Your reviewer . . suggests that in the absence of documentary evidence $I$ would feel constrained to deny the existence of Nelson and Napoleon. My contention is that in the absence of documentary evidence we should none of us have heard of Nelson and Napoleon." In reply, the reviewer says that, in effect, Lord Raglan appears to agree. In so far as Nelson and Napoleon are characters in the folk drama, they stand on the same footing as Robin Hood, Maid Marian and the rest. These two names, however, were not an effort of invention, but were chosen as those of the popular hero and bogey of the day. Their survival in this form is an effect of folk memory and not of documentary evidence, and their appearance in a ritual does not preclude their real existence, however incongruous their dramatic action. In this instance, the inference happens to be supported by documentary evidence. The conclusion to the contrary, however, that is, that without documentary evidence we should not know of their existence, is shown not necessarily to hold good. Approved documentary evidence is the only source of certain knowledge, and to this extent Lord Raglan is above criticism; but the archæologist maintains, on the other hand, that a legend may embody facts which may in certain conditions afford a clue to interpretation, when his evidence points in a certain direction. The story of the Minotaur may be ritualistic ; but the setting of the Minoan civilization is the fact to which it gave Sir Arthur Evans the clue. It may be true that, strictly speaking, in the absence of documentary evidence we have no certain knowledge of Minos; but we have all heard and believe in the existence of the head of the great empire, for whom his name is the generic term.

\section{Russian Railway Transport}

AT the International Exhibition of Art and Technique in Modern Life which is to be opened in Paris this month, Soviet railway transport will be well represented, the principal exhibit being a working 
model of the new locomotive SO 17-635 which recently completed a successful test journey of 13,000 miles hauling a goods train of 1,200 tons. This engine is an outstanding development of the steam locomotive and, in its way, a pioneer, having been designed for the conditions of Middle Asia and the Far East where, owing to the scarcity of water, the provision of adequate supplies may represent as much as 40 per cent of the total cost of construction. The engine has a special tender equipped with radiators for condensing the exhaust steam, and tanks for collecting the condensate. After being passed first through an oil separator, the exhaust steam enters a turbine which drives the fans for cooling the steam when it reaches the radiators. In this way, with an initial supply of 10 tons of water, it is claimed that the engine can make a run of 627 miles without replenishment. The trial trip was organized for the purpose of testing the behaviour of this locomotive in severe winter conditions, with different kinds of coal, and on the steep gradients which are numerous in the mountainous districts. Travelling from Moscow to Vladivostok and back, it passed over eleven main lines of the U.S.S.R., and the long run, it is stated, was completed without a hitch. Further Soviet exhibits at the Paris Exhibition will include working models of other steam and electric locomotives and of new types of railway coaches specially adapted to Russian and transSiberian conditions of travel. The growth of railway transport in those regions is indicated by recent official figures, which show that in 1935 the total length of the railways in the U.S.S.R. was 52,500 miles and that last year they carried 990.8 million passengers and $484 \cdot 2$ million tons of freight.

\section{Research in Tropical Medicine}

THRes junior fellowships are offered immediately by the Medical Research Council for award to qualified medical men wishing to receive training with the view of careers in research work in tropical medicine. The fellowships will be tenable for three years. The stipend will be at the rates of $£ 300, £ 400$ and $£ 500$ per annum in the successive years, with an additional allowance during service abroad and necessary expenses. In three years' time, at least one senior fellowship will be available for candidates who have held the junior fellowships mentioned above. This will be awarded for a further period of three years, carrying stipend at the rate of $£ 600-£ 750$ per annum, with an additional allowance during service abroad and expenses. The time will be spent mainly in research work in the tropics. The Council is also prepared to consider immediate applications for senior fellowships from candidates who have had adequate experience in research work, whether already specially trained in tropical medicine or not. The Council further intends to establish in due course permanent and pensionable appointments for research work in tropical medicine, including senior posts. Members of this research staff will work partly in the tropics, and partly in institutions at home to which they will be severally attached. Further information can be obtained from the Secretary, Tropical Medical Research Committee, 38 Old Queen Street, London, S.W.1, with whom applications should be lodged not later than June 15.

\section{Royal Geographical Society Awards}

THe King has approved the award of the Royal Medals of the Royal Geographical Society as follows : The Founder's Medal to Colonel C. G. Lewis, for his surveys on the Miri Mission, 1911-12, in Iraq and Syria, 1918-19, and on the Afghan and Turco-Iraq Boundary Commissions; for the air survey of the Irrawaddy Delta, 1924; and for his promotion and encouragement of the exploration and survey of the Himalaya; The Patron's Medal to Mr. Lincoln Ellsworth, for his work in developing the technique of aerial navigation in the Polar regions, culminating in his successful flight across the Antarctic in 1935-36. The following awards have been made by the Council : The Murchison Grant to Mr. Ronald Kaulback, for his surveys in South-eastern Tibet; the Back Grant to Mr. L. R. Wager, for his work in mountain physiography; the Cuthbert Peek Grant to Mr. V. E. Fuchs, to assist him in his expedition to Lake Rukwa, East Africa; the Gill Memorial to Mr. George B. Barbour, for his work on the geology and geography of China.

\section{Institution of Electrical Engineers Premium Awards}

THE Institution of Electrical Engineers has made the following award of premiums for papers read during the Session 1936-37, or accepted for publication : Institution Premium to Dr. E. A. Speight and O. W. Gill ; Ayrton Premium to Dr. D. Robertson; Fahie Premium to Col. A. S. Angwin and Mr. R. A. Mack; Kelvin Premium to Dr. T. E. Allibone, D. B. McKenzie and F. R. Perry ; Paris Exhibition (1881) Premium to J. A. Sumner; Overseas Premium to Dr. A. L. Green, Dr. G. Builder and Dr. O. O. Pulley ; Extra Premiums to Dr. P. Dunsheath, L. H. Harris, E. H. Jolley and F. O. Morrell ; H. Trencham and K. J. R. Wilkinson; Mr. W. R. Debenham; Dr. W. Jack. son, Mr. H. A. Thomas; Wireless Section Premiums to Dr. Benjamin, C. W. Cosgrove, and G. W. Warren (Duddell Premium); Commander F. G. Loring, W. L. McPherson and W. H. McAllister, T. L. Eckersley; Meter and Instrument Section Premiums to W. F. Randall ; Dr. E. Hughes ; Dr. C. Dannatt ; Prof. J. T. MacGregor-Morris and Mr. V. A. Hughes; Transmission Section Premiums to H. G. Taylor (Sebastian de Ferranti Premium); J. Eccles.

\section{Radio Communication Conference at Bucharest}

The Fourth Reunion of the Comité Consultatif International des Radiocommunications (C.C.I.R.) will take place in Bucharest on May 21-June 8. The previous meeting was held in Lisbon in 1934 (see NATURE Sept. 29, p. 490), and in the intervening three years the various national committees have investigated miscellaneous technical problems in connexion with radio communication. The matters under discussion at the present time include the study of the propaga- 